\title{
Critical thinking at Rwanda's public universities: Emerging evidence of a crucial development priority
}

Since the late 1990s, Rwanda has spent a larger proportion of its education budget on higher education than almost any other country in sub-Saharan Africa (World Bank, 2004). In the years immediately following the genocide in 1994, the government invested heavily in the reestablishment of its decimated higher education sector. Since 2000 , the emphasis has shifted from reconstruction to expansion, largely as a result of the crucial role assigned to higher education within Vision 2020, Rwanda's national development strategy (Murenzi \& Hughes, 2006; Tikly \& UK Department for International Development, 2003).

Despite such support for the sector, highly-skilled workers continue to be recruited from outside Rwanda to fill technical and leadership posts across the country (Hayman, 2005; R. Palmer, Wedgwood, Hayman, with King, \& Thin, 2007). Given the high cost of expatriate employees and the government's rhetoric of self-reliance, the continued dependence on foreign workers suggests that employers may not be able to find university graduates with similar skills within Rwanda (Hayman, 2005). Indeed, in two recent surveys of employers in Rwanda, critical thinking and problem solving skills emerged as areas of particular concern (Africa-UK Engineering for Development Partnership, 2012; Republic of Rwanda National Council for Higher Education, 2011). Although these surveys suggest that Rwandan universities may not be supporting the development of such skills in their student populations, there has never before been an empirical study available to corroborate such an interpretation. A few studies have investigated the role of critical thinking in the secondary school curriculum in Rwanda (Freedman, Weinstein, Murphy, \& Longman, 2011; McLean Hilker, 2011; Rutayisire, Kabano, \& Rubagiza, 2004; Walker-Keleher, 2006), but no analysis has ever been conducted at the university level.

This study aimed to fill this gap by empirically investigating whether students at three of Rwanda's public institutions appear to be improving in their critical thinking ability during their time at university. The study followed a sequential mixed-methods design. During the first phase of the study, an adapted version of a performance-task-based assessment of critical thinking was administered to a random sample of first- and fourth-year students attending three of the public universities in Rwanda. The second phase of the study aimed to contextualise and expand upon the assessment results by qualitatively investigating the institutional environment at two of the participating universities. This paper presents the findings from the study's initial phase. ${ }^{1}$ It begins with a discussion of the theoretical background and a description of the methodology of the first

\footnotetext{
${ }^{1}$ The results of the case study analysis are available in Author (2013).
} 
phase of the study. The assessment results are then presented, and implications of the findings for Rwanda's development strategy are elaborated.

\section{Theoretical Background}

Despite widespread consensus around its importance as an educational objective, critical thinking remains a highly debated construct. There is little agreement over the definition of the term, and there are questions about how the construct should be conceived, taught and assessed. In order to investigate the acquisition of critical thinking skills in the Rwandan context, it was therefore necessary to begin the study by building a conceptual framework that could both define the central construct in light of these ongoing debates and justify the selection of variables for consideration during analysis.

As this study aimed to assess critical thinking within Rwandan universities, it was most appropriate to identify a conceptualisation of critical thinking representative of the use of the term within the Rwandan education policy literature. A review of relevant documentation (e.g. MINEDUC, 2007; 2010) indicates that 'critical thinking' is broadly viewed as a general ability that can be fostered within a particular academic discipline and then applied to a multitude of potential situations outside of the classroom. This conceptualisation of critical thinking resonates closely with Kuhn's (1999) theory of critical thinking development. Kuhn's research has indicated that, through the study of discrete academic subjects, individuals develop a number of "meta-knowing competencies" (i.e. cognitive and metacognitive skills, as well as an increasingly sophisticated level of epistemological development), which can then be applied to ill-structured problems across domains. As cognition, metacognition and epistemology have all been found to follow developmental trajectories (Baxter Magolda, 1992; King \& Kitchener, 1994; Kuhn, 1995; Perry \& Harvard University Bureau of Study Counsel, 1970; Piaget, 1975; Vygotsky, Cole, \& Luria, 1978), Kuhn suggests that critical thinking should also be viewed in developmental terms.

Although Kuhn's theory implies that critical thinking can be developed over time, it does not necessarily follow that university education supports this trajectory. However, there is empirical evidence to suggest that critical thinking can be improved as a result of university education. In their meta-analysis of university impact in the U.S., Pascarella and Terenzini (2005) conclude that students do improve in their critical thinking ability during university. Studies referenced in the analysis (e.g. N. C. Facione \& Facione, 1997; Hagedorn et al., 1999; Mines, King, Hood, \& Wood, 1990) find statistically significant improvements on multiple measures of critical thinking, as well as similar constructs such as reflective judgment (Baxter Magolda, 1990; King \& Kitchener, 1994), with two additional studies also indicating a modest improvement in the disposition to think critically during university, as assessed via the California Critical Thinking Disposition Inventory (N. C. Facione \& 
Facione, 1997; Giancarlo \& Facione, 2001). Gains in these studies are identifiable whether or not controls are included for maturation and/or pre-university characteristics and regardless of the study time frame (i.e. gains in different studies were observed after one year, three years and four years of university). Such results have also been confirmed within individual institutions (e.g. Hatcher, 2009) and in other national contexts. In a recent study of more than 3,500 students in Colombia, Saavedra and Saavedra (2011) found that fourth-year university students demonstrated significantly higher critical thinking ability (as measured via the Graduate Skills Assessment) than first-year students.

However, it is also clear that critical thinking does not automatically improve as a result of university attendance. In the U.S., two large-scale studies have recently considered this question. In a longitudinal study of 2,500 American undergraduates enrolled at 24 institutions, Arum and Roksa (2011) observed that students did not generally improve in their critical thinking ability - as measured by the Collegiate Learning Assessment (CLA) - during their first two years at university. In a similar study of over 2,000 students enrolled at 17 liberal arts institutions, the Wabash Study of Liberal Arts Institutions report that students only improve by an average of $1 \%$ on the Collegiate Assessment of Academic Proficiency Critical Thinking Test (Blaich \& Wise, 2010). Such findings have also been supported by studies in other contexts. Pithers and Soden (1999) found no significant improvement in critical thinking ability amongst university students in Scotland and Australia (as assessed via the Smith Whetton Critical Reasoning Test), while Phan's (2011) longitudinal analysis of over 200 students in Hong Kong actually indicates a decline in the use of critical thinking during university.

On balance, the evidence suggests that a university education can improve critical thinking ability but that such improvement cannot be assumed, given the diversity in institutional environments. Astin (1970) has suggested that learning outcomes at university should be seen as a function of both inputs (e.g. the demographic characteristics, family backgrounds, and pre-university experiences of incoming students) and the university environment. In his widely used InputEnvironment-Outcome model, inputs are assumed to shape outcomes both directly and indirectly, as they can both have a direct impact on an outcome and shape the way in which students interact with their university environment. The conceptual framework developed for this study (included below as Figure 1) took Astin's model as a basic starting point. A review of the available empirical literature was then undertaken in order to populate the framework with individual and institutional factors found to affect the development of critical thinking ability in other university contexts. 
Figure 1: Conceptual Framework

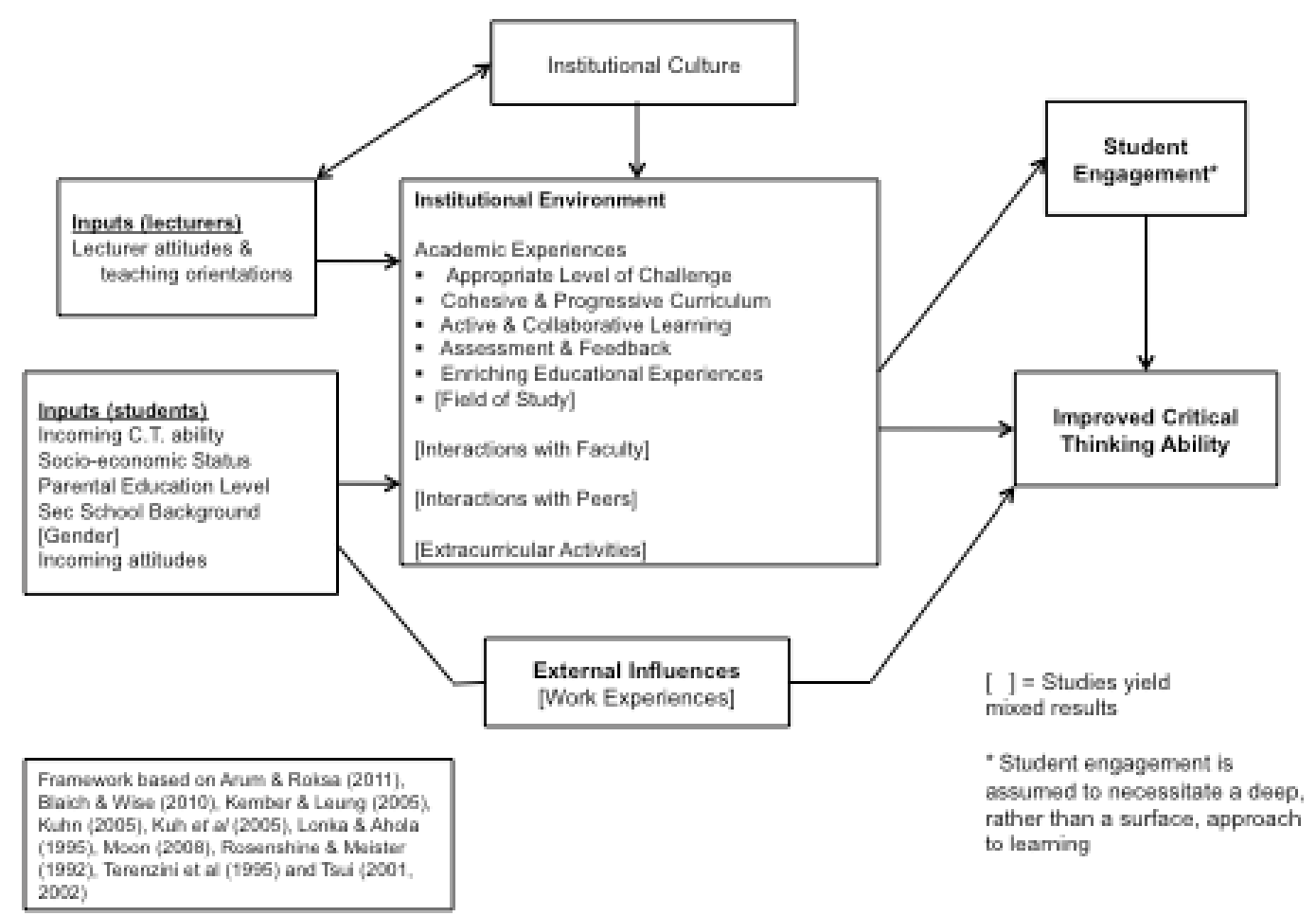

When taken as a whole, the existing body of evidence suggests that it is the nature of the academic experiences provided within universities that has the most profound effect on the development of student critical thinking skills (Kember \& Leung, 2005; Kuhn, 2005; Lonka \& Ahola, 1995; Rosenshine \& Meister, 1992; Terenzini, Springer, Pascarella, \& Nora, 1995; Tsui, 2002). Some have argued that this effect is systematically related to a student's academic discipline. Facione (1991) found significant differences between the post-test scores of students enrolled in different academic fields. Lehman and Nisbett (1990) observed dissimilarities in the reasoning skills of students enrolled in different fields of study, while Palmer and Marra (2004) identified differences in epistemology across domains, arguing that the variation was likely to be linked to differences in the academic experiences between disciplines. However, other studies (e.g. Schommer and Walker, 1995; Terenzini, Springer, Pascarella, \& Nora, 1995) have found no systematic differences between students enrolled in different disciplines. One potential explanation for such conflicting findings is that variation in critical thinking ability along disciplinary lines may actually be the result of preuniversity characteristics related to the selection of academic subject, rather than any systematic variation in the qualitative experiences of different academic disciplines. Indeed, in their study, Terenzini et al. (1995) observed that any discrepancies between disciplines tended to disappear when pre-university differences were taken into account. Arum and Roksa (2011) found a similar 
effect in their sample. Pascarella and Terenzini (2005) and Moon (2008) have also supported this argument, noting that factors which appear to have a particularly significant effect on critical thinking - such as pedagogy, curriculum, and interactions between instructors and students - are not necessarily correlated with particular fields of study.

The evidence is clearer in relation to other individual factors that appear to influence the development of critical thinking ability within universities. First, the evidence suggests that students entering university with high levels of critical thinking ability appear to further develop their ability faster than those entering with lower levels (Arum \& Roksa, 2011; Phan, 2011). Second, a number of background variables, including gender, socio-economic status, parental education level and secondary school background, have been found to be strongly correlated with both incoming critical thinking ability and the potential for a student to improve in their critical thinking skills during university (Arum \& Roksa, 2011; P. A. Facione, 1991; Shavelson, 2010; Terenzini, Springer, Yaeger, Pascarella, \& Nora, 1994).

There were concerns from the outset about the relevance of some of the above-mentioned results for a study in Rwanda, given that most of the available studies were conducted in non-African - and, in many cases, high-income - contexts. It seemed likely that critical thinking might be affected by additional inputs in Rwanda that had simply not been investigated elsewhere, or that certain aspects of the university environment found to positively influence critical thinking elsewhere might not have the same effect in Rwanda. As there was no directly relevant evidence available to consult, the conceptual framework was developed based on studies conducted in a diversity of cultural contexts. However, an assessment of the framework's applicability to the Rwandan context was identified as an explicit objective of the study.

\section{Methodology}

The primary objectives, however, were: (1) to determine the extent to which Rwandan students appear to be improving in their critical thinking ability during their time at university, and

(2) to identify the factors that seem to help or hinder the acquisition of critical thinking skills at Rwanda's universities. These objectives were rearticulated as three central research questions:

1) Is there evidence that Rwandan students are improving in their critical thinking ability during their time at university?

2) What individual and institutional factors appear to be associated with student critical thinking ability in Rwanda?

3) How are Rwandan universities helping (or hindering) the development of critical thinking skills in their students? 
The first two research questions were explored through the administration of a critical thinking assessment; the third question was investigated via a series of institutional case studies. ${ }^{2}$

The critical thinking assessment used in the study was adapted from the performance-task component of the Collegiate Learning Assessment (CLA) and took the form of a 'real-world' scenario, in which participants were asked to make a decision about a problem, using evidence from a series of related documents (Benjamin et al., 2009). The CLA format was selected due to its close correlation with Kuhn's theory of critical thinking development (which, in turn, reflects the conceptualisation of critical thinking presented in the Rwandan policy literature). Kuhn's research indicates that critical thinking involves the intentional application of a number of discrete cognitive skills (e.g. analysis and use of evidence, evaluation of arguments, etc.). The performance task component of the CLA assesses respondent ability to apply a similar list of cognitive skills to realistic, ill-structured problems. Specifically, CLA performance tasks are intended to assess respondent ability to:

"Interpret[e], analys[e] and evaluat[e] the quality of information; Identify information that is relevant to a problem, highlighting connected and conflicting information, detecting flaws in logic and questionable assumptions; Explain why information is credible, unreliable, or limited; Consider and weigh information from discrete sources to make decisions (draw a conclusion and/or propose a course of action) that logically follow from valid arguments, evidence and examples; Consider the implications of decisions and suggesting additional research when appropriate" (Chun, 2008, p. 42)

The basic format of a CLA performance task was therefore considered an appropriate measure for use in the study, although the specific content of the assessment questions needed to be adapted for use in Rwanda. ${ }^{3}$ Participant responses were scored against a rubric developed explicitly for the study, which assessed participant ability to demonstrate nine individual critical thinking skills. ${ }^{4}$

In addition to the critical thinking assessment, participants completed a short demographic questionnaire, developed explicitly for the study, which included questions about all of the

\footnotetext{
2 Due to space constraints, the case study results are reported elsewhere (Author, 2013).

${ }^{3}$ A detailed discussion of the assessment adaptation process can be found in Author (2013).

${ }^{4}$ The nine skills were: (1) The ability to recognise potential sources of bias (Skill A: Bias); (2) The ability to determine whether or not information is relevant to a situation (Skill B: Relevance); (3) The ability to recognise when source of information is not credible or reliable (Skill C: Credibility); (4) The ability to identify statistical or methodological errors in presented information (Skill D: Errors); (5) The ability to demonstrate whether or not information can be generalised and/or applied to other situations (Skill E: Generalisability); (6) The ability to recognise when there is a lack of information (Skill F: Missing Information); (7) The ability to evaluate whether or not information is connected and, if so, whether the data is conflicting or complementary (Skill G: Evaluation of Connections); (8) The ability to evaluate whether or not information supports or contradicts an argument (Skill H: Evaluation of Support); and (9) The ability to draw on valid evidence when formulating a decision (Skill I: Use of Evidence).
} 
individual factors included in the conceptual framework. ${ }^{5}$ Questions regarding participant gender, family background, secondary school, field of study and enrolment status were drafted by the author. Questions from the most recent Demographic Health Survey (DHS) completed in Rwanda (MOH Rwanda, NISR, \& ICF Macro, 2009) were also included as a means of collecting information about participant socio-economic status. ${ }^{6}$

The study took a cross-sectional approach, comparing the assessment scores of fourth-year students to the scores of first-year students as a proxy for growth. Longitudinal analysis was not possible given the time frame of the study. Some studies of university impact have attempted to create a longitudinal effect by capturing self-report measures of cognitive gains (Astin, 1991). However, self-report measures are notoriously unreliable indicators of student growth (Pascarella, Seifert, \& Blaich, 2010). As the major objection to the use of cross-sectional designs when studying university impact is the confounding effect of high attrition rates within student populations (Saavedra \& Saavedra, 2011) - and as attrition is not a significant problem at Rwanda's public universities due to the high proportion of scholarship recipients - a cross-sectional design was gauged to be a satisfactory method for the study.

Participating institutions were selected through a modified two-stage cluster sample strategy (Scheaffer, Mendenhall, \& Ott, 2006). As only six universities fit the study's eligibility criteria (i.e. public universities with more than 100 students), it was illogical to draw a probability sample at the first stage. ${ }^{7}$ Instead, three universities were purposively sampled from the six in the sampling frame. At the time of sampling, Rwanda's public higher education sector included one traditional comprehensive university and a number of technical colleges focused on particular academic subjects. ${ }^{8}$ Given the important differences between 'niche' institutions and multi-faculty universities, it was determined that the study should focus on the National University of Rwanda (NUR), along with two technical institutes: the Kigali Institute of Science \& Technology (KIST) and the School of Finance \& Banking (SFB). In addition to representing a diversity of institutional structures,

\footnotetext{
${ }^{5}$ Participants' academic experiences were explored during the second, qualitative phase of the study, so they did not feature in the study questionnaire.

${ }^{6}$ Both the adapted assessment and the questionnaire were field-tested and piloted in Rwanda prior to data collection.

7 The study focuses on Rwanda's public institutions because they have benefited the most from the government's high levels of support for higher education. In addition to directly funding public universities, the government's merit-based bursaries are reserved for use at public institutions, meaning that those students finishing secondary school with the highest examination scores are overwhelmingly likely to attend public universities. The public sector is also more representative of Rwanda's total student population, as private institutions are generally populated by wealthier students who are able to pay the required tuition fees.

8 In 2014, Rwanda's public institutions were re-designated as constituent colleges of the consolidated University of Rwanda.
} 
the three institutions offered the advantage of a study population that was likely to be relatively homogeneous in terms of background academic ability. Widely considered to be the most prestigious public institutions in the country, NUR, KIST and SFB are largely populated with government scholarship recipients. As a result, the student populations tend to exhibit similar levels of incoming academic ability while also representing a diversity of socio-economic and family backgrounds.

Potential participants were selected randomly from university enrolment lists. Power analysis conventions (advocated by Cohen, 1977) were used to determine a total required sample size of 96 participants from each institution. Assuming that approximately $30 \%$ of those contacted would opt not to participate (a convention advocated by Israel, 1992), 150 students were selected from each institution. Given the cross-sectional design of the study, institutional recruitment lists were evenly divided between first- and fourth-year students, with seventy-five students from each year being selected for recruitment at each of the three institutions. As 37 of the selected students could not be located ( 31 from NUR and six from KIST), 413 students were contacted regarding participation in the study. Of these 413,220 agreed to participate.

Data collection was conducted in February 2012. Four or five data collection sessions were organised at each institution in order to accommodate participant schedules. All sessions were held in classrooms on the university campuses, in order to make access as easy as possible for participants, and were coordinated and supervised by the author, in the company of one or two research assistants. ${ }^{9}$ During the sessions, participants completed both the assessment and the accompanying demographic questionnaire. Students were given the option of receiving their written materials in either French or English. Oral instructions were also provided in Kinyarwanda, and participants were given the option to respond to the assessment questions in French, English, Kinyarwanda or some combination. ${ }^{10}$

Following data collection, the assessment responses were translated into English by the research team. The particular challenge posed by translation in research has been extensively discussed in the literature (Bradby, 2002; Edwards, 1998; Phillips, 1960; Temple \& Young, 2004). Specifically, the interpretive act implicit in translation has raised significant concerns about the validity of using translated text as original, rather than "processed", data (Wengraf, 2001). As the assessment responses were analysed in the aggregate, it was determined that the interpretive element of translation should not pose a substantial problem for the integrity of the data in the

\footnotetext{
${ }^{9}$ Nine Rwandan university students worked as research assistants on the study.

${ }^{10}$ Given recent changes in language of instruction in Rwanda, it was assumed that some participants would have only "partial knowledge" of both French and English, so participants were allowed to respond in a combination of any of the three languages (as suggested by Hambleton, 1994).
} 
study. However, the research team aimed for "conceptual equivalence" (Liamputtong, 2010) between original and translated versions of the responses in order to ensure validity of the resulting assessment scores. The back-translation method advocated by Brislin (1970) was used to achieve such equivalence. Once translated, all of the completed assessments were scored by the author, ${ }^{11}$ and the assessment scores, along with all of the data from the demographic questionnaires, were manually entered into SPSS. Each entry was triple-checked to ensure data integrity, twice manually and once by verifying frequency tables.

Sample characteristics were investigated using simple frequency tables and correlational analyses (e.g. chi-square tests). The research questions were then approached through the use of analysis of variance techniques. Multivariate analysis of variance (MANOVA) was used to identify differences in the pattern of assessment scores between groups. Follow-up analysis, in which results on individual critical thinking skill scores were compared between groups, took the form of either univariate analysis of variance (ANOVA) or independent samples $t$-tests. ${ }^{12}$ All of the analysis was conducted by the author, using SPSS.

\section{Study Participants}

\subsection{Characteristics of the full sample}

Of the 220 participants, 103 were students at NUR (47\%), 82 were from KIST (37\%) and 35 were from SFB (16\%). As planned, the sample was divided relatively evenly between first- and fourth-year students at KIST and NUR. Most SFB participants, however, were in their first year.

Table 1: Participant Year at University, by Institution ( $n=220)$

\begin{tabular}{c|cccc} 
Institution & $\begin{array}{c}\text { Frequency First- } \\
\text { Year Participants }\end{array}$ & $\begin{array}{c}\text { \% First-Year } \\
\text { Participants }\end{array}$ & $\begin{array}{c}\text { Frequency Fourth- } \\
\text { Year Participants }\end{array}$ & $\begin{array}{c}\text { \% Fourth-Year } \\
\text { Participants }\end{array}$ \\
\hline NUR & 56 & 54.4 & 47 & 45.6 \\
KIST & 46 & 56.1 & 36 & 43.9 \\
SFB & 24 & 68.6 & 11 & 31.4 \\
Total & 126 & 57.3 & 94 & 42.7
\end{tabular}

Most of the study participants were male (78.6\% of the overall sample). Although the student populations of the three institutions are also predominantly male, the gender distribution of the study sample, as outlined in Table 2, reflects an under-sampling of female participants, particularly at SFB.

\footnotetext{
${ }^{11}$ A random sample of $10 \%$ of the assessments was double-scored in order to test for reliability in scoring. The scoring was found to be sufficiently reliable to allow for subsequent analysis.

12 Individual ANOVAs were used for variables with multiple categories (e.g. parental education level), while independent samples $t$-tests were used for binary variables (e.g. gender).
} 
Table 2: Participant Gender, by Institution ( $n=220)$

\begin{tabular}{|c|c|c|c|c|}
\hline Institution & $\begin{array}{c}\text { Frequency Male } \\
\text { Participants }\end{array}$ & $\begin{array}{c}\% \text { Male } \\
\text { Participants }\end{array}$ & $\begin{array}{c}\text { Frequency Female } \\
\text { Participants }\end{array}$ & $\begin{array}{l}\text { \% Female } \\
\text { Participants }\end{array}$ \\
\hline NUR & 76 & $\begin{array}{c}73.8 \\
\text { \% Males in NUR } \\
\text { Student Body: } 68.6\end{array}$ & 27 & $\begin{array}{c}26.2 \\
\text { \% Females in NUR } \\
\text { Student Body: } 31.4\end{array}$ \\
\hline KIST & 68 & $\begin{array}{c}82.9 \\
\text { \% Males in KIST } \\
\text { Student Body: } 75\end{array}$ & 14 & $\begin{array}{c}17.1 \\
\text { \% Females in KIST } \\
\text { Student Body: } 25\end{array}$ \\
\hline SFB & 29 & $\begin{array}{c}82.9 \\
\text { \% Males in SFB } \\
\text { Student Body: } 58.2\end{array}$ & 6 & $\begin{array}{c}17.1 \\
\text { \% Females in SFB } \\
\text { Student Body: } 41.8\end{array}$ \\
\hline Total & 173 & 78.6 & 47 & 21.4 \\
\hline
\end{tabular}

Source: NUR Department of Planning \& Development (2012); KIST Office of Planning \& Development (2012); SFB Directorate of Academic Services (2012)

Data regarding participant performance on the National Examination confirmed expectations that the overall sample would be relatively homogeneous in terms of incoming academic ability. Participants were asked if their National Examination score had made them eligible for a government bursary. ${ }^{13}$ The majority of the sample had sufficiently high exam scores to qualify for a scholarship in their year (183 participants, or $83.2 \%$ of the sample), confirming that most participants had obtained the highest possible marks in their subject on the National Examination.

Perhaps unsurprisingly, given the random nature of the sample, participants represented a range of secondary school backgrounds. Just over half had attended a public secondary school, $42 \%$ a private religious school, and 7\% a private non-religious school; the sample was divided almost equally between those describing their background as rural and those hailing from urban areas (54.1\% and $45.9 \%$, respectively).

On the questionnaire, participants were asked to indicate the highest level of education that any adult in their household had completed. Responses were grouped into four overall categories: Some Primary Education, Some Secondary Education, Some Tertiary Education, and No Education/No Adults in the Household. The distribution of these categories is outlined in Table 3.

\footnotetext{
${ }^{13}$ Secondary school students in Rwanda specialise in three subjects during their final three years. At the end of secondary school, students take a National Examination in their subjects. National Examination scores are used to determine who will receive government bursaries for university.
} 
Table 3: Highest Level of Parental Education, by Institution $(n=214)^{14}$

\begin{tabular}{c|cccc} 
Institution & $\begin{array}{c}\text { Frequency and } \\
\text { \% Some } \\
\text { Primary } \\
\text { Education }\end{array}$ & $\begin{array}{c}\text { Frequency and } \\
\text { \% Some } \\
\text { Secondary } \\
\text { Education }\end{array}$ & $\begin{array}{c}\text { Frequency and } \\
\text { \% Some } \\
\text { Tertiary } \\
\text { Education }\end{array}$ & $\begin{array}{c}\text { Frequency and } \\
\text { \% No Adults or } \\
\text { No Adults with } \\
\text { Education }\end{array}$ \\
\hline NUR & $30(29.1 \%)$ & $25(24.3 \%)$ & $11(10.7 \%)$ & $35(34 \%)$ \\
KIST & $21(25.6 \%)$ & $16(19.5 \%)$ & $21(25.6 \%)$ & $21(25.6 \%)$ \\
SFB & $5(14.3 \%)$ & $9(25.7 \%)$ & $4(11.4 \%)$ & $16(45.7 \%)$ \\
Total & $56(26.2 \%)$ & $50(23.4 \%)$ & $36(16.8 \%)$ & $72(33.6 \%)$
\end{tabular}

These data suggest that participants from KIST were the most likely to have come from families in which some of the adults had completed tertiary education. This may be related to the fact that more affluent families in Rwanda are more likely to have the means to send their children to the private, fee-paying secondary schools that tend to specialise in science subjects (a pre-requisite for admission to KIST).

The socio-economic status of participants was determined using an asset-based index, constructed through the use of principal components analysis (PCA) on the DHS asset questions included in the questionnaire (as advocated by Filmer \& Pritchett, 2001; Gwatkin et al., 2007; McKenzie, 2003; Rutstein \& Johnson, 2004). Participant distribution in terms of socio-economic status is outlined in Table 4.

Table 4: Wealth Quintiles, by Institution ( $n=220)$

\begin{tabular}{|c|c|c|c|c|c|}
\hline Institution & $\begin{array}{c}\text { Frequency } \\
\text { and \% } \\
\text { Highest } \\
\text { Wealth } \\
\text { Quintile }\end{array}$ & $\begin{array}{c}\text { Frequency } \\
\text { and \% } \\
\text { Second-to- } \\
\text { Highest } \\
\text { Wealth } \\
\text { Quintile }\end{array}$ & $\begin{array}{c}\text { Frequency } \\
\text { and \% } \\
\text { Middle } \\
\text { Wealth } \\
\text { Quintile }\end{array}$ & $\begin{array}{c}\text { Frequency } \\
\text { and \% } \\
\text { Lowest } \\
\text { Wealth } \\
\text { Quintile }\end{array}$ & $\begin{array}{c}\text { Frequency } \\
\text { and \% } \\
\text { Missing } \\
\text { Quintile }\end{array}$ \\
\hline NUR & $21(20.4 \%)$ & $16(15.5 \%)$ & $10(9.7 \%)$ & 49 (47.6\%) & $7(6.8 \%)$ \\
\hline KIST & 16 (19.5\%) & 17 (20.7\%) & 6 (7.3\%) & 36 (43.9\%) & 7 (8.5\%) \\
\hline SFB & 4 (11.4\%) & $8(22.9 \%)$ & $6(17.1 \%)$ & 13 (37.1\%) & $4(11.4 \%)$ \\
\hline Total & 41 (18.6\%) & 41 (18.6\%) & 22 (10.0\%) & 98 (44.5\%) & $18(8.2 \%)$ \\
\hline
\end{tabular}

As with parental education level, it appears that participants from KIST were more likely to come from more affluent economic backgrounds than participants from the other institutions.

Participants were also asked about their academic discipline. Questions pertaining to academic faculty and department were open-ended in nature. The resulting diversity of responses yielded cells with very few (i.e. one or two) cases. Responses were therefore aggregated into two

\footnotetext{
14 Five participants did not respond to the question, and one responded that he or she did not know the highest level of education. These six responses were classified as missing data for this field.
} 
overall categories: Sciences \& Engineering, ${ }^{15}$ and Social Sciences \& Humanities. ${ }^{16}$ The disciplinary distribution within the sample is outlined in Table 5.

Table 5: Academic Field of Study, by Institution $(n=220)$

\begin{tabular}{|c|c|c|c|c|}
\hline Institution & $\begin{array}{l}\text { Frequency } \\
\text { Sciences \& } \\
\text { Engineering }\end{array}$ & $\begin{array}{c}\text { \% Sciences \& } \\
\text { Engineering }\end{array}$ & $\begin{array}{c}\text { Frequency } \\
\text { Social Sciences } \\
\text { \& Humanities }\end{array}$ & $\begin{array}{c}\text { \% Social Sciences \& } \\
\text { Humanities }\end{array}$ \\
\hline NUR & 47 & $\begin{array}{r}45.6 \\
\text { \% Sciences \& Engineering } \\
\text { in NUR Student Body: } \\
45.3\end{array}$ & 56 & $\begin{array}{c}54.4 \\
\text { \% Social Sciences \& } \\
\text { Humanities in NUR } \\
\text { Student Body: } 54.7\end{array}$ \\
\hline KIST & 82 & $\begin{array}{l}100.0 \\
\text { \% Sciences \& Engineering } \\
\text { in KIST Student Body: } \\
100\end{array}$ & 0 & $\begin{array}{r}0.0 \\
\text { \% Social Sciences \& } \\
\text { Humanities in KIST } \\
\text { Student Body: } 0\end{array}$ \\
\hline SFB & 0 & $\begin{array}{c}0.0 \\
\text { \% Sciences \& Engineering } \\
\text { in SFB Student Body: } 0\end{array}$ & 35 & $\begin{array}{r}100.0 \\
\text { \% Social Sciences \& } \\
\text { Humanities in SFB } \\
\text { Student Body: } 100\end{array}$ \\
\hline Iotal & & & & \\
\hline
\end{tabular}

Source: NUR Department of Planning \& Development (2012); KIST Office of Planning \& Development (2012); SFB Directorate of Academic Services (2012)

In terms of language, 95 participants chose to respond to the assessment in English, 91 in French, 17 in Kinyarwanda and 17 in some combination. Language of response was fairly similarly distributed within the three institutions.

\subsection{Characteristics of the first- and fourth-year sub-samples}

The validity of cross-sectional comparisons relies on the similarity of comparison groups, so it was important to verify the similarity of the first- and fourth-year sub-samples prior to analysis. As random sampling was used to determine the participant population, it was assumed that the subsamples would be broadly comparable. However, this assumption was verified by comparing the characteristics of participants in the two sub-samples, in order to highlight any potentially problematic differences.

It was not possible to compare the sub-samples on any measure of incoming critical thinking ability, but, as prior studies have indicated limited encouragement of critical thinking skills in Rwandan secondary schools (e.g. Rutayisire, Kabano, \& Rubagiza, 2004), it was assumed that

\footnotetext{
${ }^{15}$ Comprising participants studying Engineering, Applied Sciences, Sciences, Architecture \& Design, Medicine, Pharmacy, Psychology and Agriculture

${ }^{16}$ Comprising participants studying Business (Economics, Management or Finance), Arts, Media, Social Sciences and Law
} 
students in the two populations would have entered university with similarly low levels of critical thinking ability. However, this assumption could not be empirically verified.

It was, however, possible to verify differences between the background characteristics of students in the two sub-samples, and, in fact, differences could be identified. The proportion of male students was slightly higher in the fourth-year sub-sample ( $82 \%$ versus $77 \%$ in the first-year sample). The fourth-year sub-sample also included a higher proportion of students whose parents had completed tertiary education ( $21 \%$ versus $15 \%$ ) and who came from more affluent economic backgrounds ( $24 \%$ of the fourth-year participants were in the highest wealth quintile, as opposed to $14 \%$ of the first-year participants). Fourth-year students were also slightly more likely to have been eligible for a government scholarship ( $90 \%$ versus $81 \%)$. There was no difference in the distribution of academic subjects between the two groups (61\% of first-year participants were in Science subjects, as were $60 \%$ of fourth-year participants). Prior research suggests that all of these identified differences would tend to have advantaged the fourth-year population.

It is also likely that the two groups differed in terms of aptitudes that can be assumed to improve during university. In the Rwandan context, language ability is the most obvious aptitude in this category. Although many of Rwanda's public universities have long used English as their primary language of instruction, most secondary schools taught exclusively in French until the national change in language of instruction in $2010 .{ }^{17}$ The academic calendar in Rwanda is such that those entering university in January 2012 (i.e. the first-year participants in this study) would have completed secondary school at the end of 2010. Fourth-year participants are therefore likely to have been more comfortable reading and writing in English than those in their first year of university. In fact, a significant correlation can be identified in the sample between language of response and year at university $[\chi(2)=23.475, p<.001$, contingency coefficient $=.311]$, with fourth-year students being more likely than their first-year counterparts to have elected to use English.

It is also likely that fourth-year participants would have been more comfortable with an open-ended assessment format than the first-year participants, as open-ended examinations are unusual in Rwandan secondary schools. This may have given the fourth-year participants a slight advantage when approaching the critical thinking assessment. This possibility was investigated by analysing differences between the two groups in terms of the length of time taken to complete the assessment. Participants were given no time limit for completing the assessment, as it was determined that a time limit could put undue stress on the testing situation, while contributing nothing to the research objectives. However, start and end times were recorded during data

\footnotetext{
17 In 2010, English became the sole language of instruction at the secondary and tertiary levels. Prior to this, a bilingual language of instruction policy had allowed institutions to choose between English and French.
} 
collection. A significant correlation could be identified between the amount of time taken to complete the assessment and year at university $[\chi(3)=19.058, p<.001$, contingency coefficient $=$ .284], with first-year participants generally taking longer than fourth years to complete their assessments. This suggests that first-year students may have needed more time than fourth-year students to understand how to respond to the critical thinking assessment. An alternative interpretation is that the difference could be indicative of higher levels of motivation within the firstyear population.

\section{Results and Discussion}

\subsection{Evidence of critical thinking ability}

The overall distribution of the assessment results is outlined in Table 6.

Table 6: Distribution of Assessment Scores $(n=199)^{18}$

\begin{tabular}{|c|c|c|c|c|c|c|}
\hline Skill & Mean & $\begin{array}{c}\text { Standard } \\
\text { Error of } \\
\text { Mean }\end{array}$ & Median & Mode & $\begin{array}{l}\text { Standard } \\
\text { Deviation }\end{array}$ & Range \\
\hline A: Bias & 2.77 & .054 & 3 & 3 & .768 & Low 1 ; High 5 \\
\hline B: Relevance & 3.07 & .088 & 3 & 4 & 1.235 & Low 1 ; High 5 \\
\hline C: Credibility & 2.48 & .044 & 3 & 3 & .618 & Low 1 ; High 4 \\
\hline $\begin{array}{c}\text { D: Errors } \\
\text { E: }\end{array}$ & 2.14 & .055 & 2 & 2 & .776 & Low 1 ; High 4 \\
\hline $\begin{array}{l}\text { Generalisability } \\
\text { F: Missing }\end{array}$ & 1.59 & .057 & 1 & 1 & .805 & Low 1 ; High 4 \\
\hline $\begin{array}{l}\text { Information } \\
\text { Composite: }\end{array}$ & 2.17 & .033 & 2 & 2 & .461 & Low 1 ; High 4 \\
\hline Evaluation ${ }^{\mathrm{b}}$ & 2.45 & .078 & 2.33 & 2 & 1.104 & Low 1 ; High 5 \\
\hline \multicolumn{7}{|c|}{$\begin{array}{l}\text { Participants were initially assigned nine individual assessment scores, corresponding to the nine } \\
\text { individual critical thinking skills assessed. However, principal components analysis indicated that } \\
\text { three of the skills were highly correlated, suggesting the existence of a latent variable. Scores on } \\
\text { the three correlated skills were subsequently averaged, leaving seven scores for subsequent } \\
\text { analysis. }\end{array}$} \\
\hline
\end{tabular}

Although the standard deviation differs between individual skills, results indicate relatively uniform variation in the range of scores obtained on the individual skills assessed. This suggests that the spread of scores is likely to be a valid representation of the range of ability within the sample.

Evidence of scores along the full range of the scoring spectrum also indicates that the assessment was at an appropriate level of difficulty for the population.

\footnotetext{
18 Twenty-one participants received a 0 on all nine sub-skills assessed, meaning that their assessment responses could not be scored. As Missing Values Analysis determined that these data were likely to be missing at random in the sample, the 21 cases were removed from the distribution prior to analysis. The final sample for analysis therefore consisted of 199 cases.
} 
Disaggregation of the first- and fourth-year results (presented in Table 7) gives a picture of the range of ability within the two sub-samples.

Table 7: Distribution of Assessment Scores, by Year ( $n=199)$

\begin{tabular}{c|ccc} 
Skill & Year & Mean & Standard Deviation \\
\hline \multirow{2}{*}{ A: Bias } & First Years $(n=112)$ & 2.79 & .725 \\
& Fourth Years $(n=87)$ & 2.75 & .824 \\
& & & \\
B: Relevance & First Years $(n=112)$ & 3.01 & 1.234 \\
& Fourth Years $(n=87)$ & 3.14 & 1.241 \\
& & & \\
C: Credibility & First Years $(n=112)$ & 2.48 & .600 \\
& Fourth Years $(n=87)$ & 2.47 & .644 \\
& & & \\
D: Errors & First Years $(n=112)$ & 2.12 & .780 \\
& Fourth Years $(n=87)$ & 2.16 & .776 \\
& & & .804 \\
E: Generalisability & First Years $(n=112)$ & 1.64 & .805 \\
& Fourth Years $(n=87)$ & 1.52 & .470 \\
& & & .437 \\
F: Missing Information & First Years $(n=113)$ & 2.11 & 1.090 \\
& Fourth Years $(n=87)$ & 2.25 & 1.104
\end{tabular}

In the aggregate, these results suggest that critical thinking ability within the study population is quite weak, as the average participant received between 1.5 and 3 out of a possible score of 5 for each skill. Although it was anticipated that first-year students would demonstrate low critical thinking ability, the poor performance of fourth-year participants implies that students may be leaving the universities in the sample with weak critical thinking skills.

These findings were found to be consistent across the participating institutions. Multivariate analysis of variance (MANOVA) was used to investigate similarities in the overall pattern of scores between the three institutions. The overall effect of Institution, as a grouping variable, on the pattern of scores was found to be non-significant, using both Wilks' lambda $(F(14,378)=1.619$, $p=.071)$ and Pillai's trace $(F(14,380)=1.621, p=.071)$. Univariate follow-ups also indicate no significant results, except in the case of Skill B: Relevance $(F(2)=6.172, p=.003$, partial eta squared $=.060) .{ }^{19}$ Results therefore indicate no systematic difference in assessment scores between

\footnotetext{
${ }^{19}$ The significant result for Skill B appears to be due to the particularly low average score for Skill B within the SFB population. (The mean score for Skill B was 2.34 at SFB, as opposed to 3.2 at NUR and 3.18 at KIST). Given the small sample of SFB students, this is likely to be a random fluctuation, rather than an actual effect related to institutional structure, particularly as all of the individual effect sizes were found to be minimal $(<.06$ for Skill $B$ and $<.03$ for all other skills).
} 
the three institutions in the sample. In addition to being an interesting finding in itself, this lack of significant between-group differences allowed scores from the three institutions to be combined into one overall distribution for subsequent analysis.

Cross-sectional studies of critical thinking ability often control for individual-level characteristics during analysis, in order to eliminate any potentially confounding effects on the cross-sectional comparison (e.g. Saavedra \& Saavedra, 2011). However, analysis of the relationship between the assessment scores and the individual-level characteristics suggested by the conceptual framework indicated no systematic effects in the study sample. Individual MANOVAs were performed on the seven dependent variables, using Gender, Wealth Quintile, Parental Education Level, Secondary School Type and Field of Study as the respective grouping variables. The overall effect of each of the five grouping variables was found to be non-significant (as outlined in Table 8).

Table 8: Results of MANOVA analysis of individual-level effects

\begin{tabular}{c|cc} 
Grouping Variable & $\begin{array}{c}\text { Results } \\
\text { (Pillai's trace) }\end{array}$ & $\begin{array}{c}\text { Significance } \\
(p \text {-value })\end{array}$ \\
\hline Gender & $F(7,190)=1.631$ & $P=.129$ \\
$\begin{array}{c}\text { Wealth Quintile } \\
\text { Parental Education } \\
\begin{array}{c}\text { Level } \\
\text { Secondary School } \\
\text { Type }\end{array}\end{array}$ & $F(21,522)=1.337$ & $P=.145$ \\
Field of Study & $F(21,570)=.422$ & $P=.990$ \\
& $F(7,190)=1.879$ & $P=.075$
\end{tabular}

For each grouping variable, univariate follow-ups were also conducted, both on the overall sample and independently within the first- and fourth-year populations. ${ }^{20}$ The results of the follow-ups broadly reflected the results of the MANOVA analysis. Two variables were found to impact incoming critical thinking ability: Gender and Field of Study. However, no such association could be detected within the fourth-year population, suggesting that any effects do not persist throughout university. No other background characteristics were found to systematically affect critical thinking ability within either the incoming or the graduating populations.

\subsection{Evidence of improvement}

In order to investigate the extent to which Rwandan undergraduates appear to improve in their critical thinking ability during their time at university, MANOVA was used to compare the

\footnotetext{
${ }^{20}$ Individual results of the univariate analysis have not been included here due to space constraints but are available from the author upon request. The complete results can also be found in Author (2013).
} 
overall pattern of the first-year assessment results with those of the fourth-year students in the sample. Independent samples $t$-tests were also conducted in order to compare first- and fourthyear performance on each of the individual critical thinking skills assessed. Given that participant background characteristics appear to have no effect on demonstrated critical thinking ability within the sample, the cross-sectional comparison was completed without any controls for individual-level effects.

The results of MANOVA, using Year in University as a grouping variable, indicates that Year in University has no significant effect on the overall pattern of scores in the sample $(F(7,190)=1.488$, $p=.174$, using Pillai's trace). Results of the follow-up $t$-tests, presented in Table 9, demonstrate a similar lack of effect. 
Table 9: Analysis of Differences in Critical Thinking Ability by Year at University ( $n=199$ )

\begin{tabular}{|c|c|c|c|c|c|c|c|}
\hline Skill & Year & Mean & $\begin{array}{l}\text { Standard } \\
\text { Deviation }\end{array}$ & $\begin{array}{c}\text { Standard } \\
\text { Error of } \\
\text { Mean }\end{array}$ & $\begin{array}{c}\text { Equal } \\
\text { variances } \\
\text { assumed? } \\
\text { (based on } \\
\text { Levene's test } \\
\text { for Equality of } \\
\text { Variances) }\end{array}$ & Results of $t$-test & $\begin{array}{c}\text { Significance } \\
\text { ( } p \text {-value) }\end{array}$ \\
\hline \multirow{2}{*}{ A: Bias } & Year $1(n=112)$ & 2.79 & .725 & .068 & \multirow{2}{*}{ Yes } & \multirow{2}{*}{$t(197)=.432$} & \multirow{2}{*}{$p=.666$} \\
\hline & Year $4(n=87)$ & 2.75 & .824 & .088 & & & \\
\hline \multirow{2}{*}{ B: Relevance } & Year 1 (n=112) & 3.01 & 1.234 & .117 & \multirow{2}{*}{ Yes } & \multirow{2}{*}{$t(197)=-.730$} & \multirow{2}{*}{$p=.466$} \\
\hline & Year $4(n=87)$ & 3.14 & 1.241 & .133 & & & \\
\hline \multirow{2}{*}{ C: Credibility } & Year 1 (n=112) & 2.48 & .600 & .057 & \multirow{2}{*}{ Yes } & \multirow{2}{*}{$t(197)=.123$} & \multirow{2}{*}{$p=.902$} \\
\hline & Year $4(n=87)$ & 2.47 & .644 & .069 & & & \\
\hline \multirow{2}{*}{ D: Errors } & Year 1 (n=112) & 2.12 & .780 & .074 & \multirow{2}{*}{ Yes } & \multirow{2}{*}{$t(197)=-.403$} & \multirow{2}{*}{$p=.687$} \\
\hline & Year $4(n=87)$ & 2.16 & .776 & .083 & & & \\
\hline \multirow{2}{*}{ E: Generalisability } & Year 1 (n=112) & 1.64 & .804 & .076 & \multirow{2}{*}{ Yes } & \multirow{2}{*}{$t(197)=1.093$} & \multirow{2}{*}{$p=.276$} \\
\hline & Year $4(n=87)$ & 1.52 & .805 & .086 & & & \\
\hline \multirow{2}{*}{ F: Missing Information } & Year 1 (n=113) & 2.11 & .470 & .044 & \multirow{2}{*}{ No } & \multirow{2}{*}{$t(190.99)=-2.277$} & \multirow{2}{*}{$p=.024^{*}$} \\
\hline & Year $4(n=87)$ & 2.25 & .437 & .047 & & & \\
\hline \multirow{2}{*}{ Composite: Evaluation } & Year 1 (n=112) & 2.298 & 1.085 & .102 & \multirow{2}{*}{ Yes } & \multirow{2}{*}{$T(196)=-2.181$} & \multirow{2}{*}{$p=.030^{*}$} \\
\hline & Year $4(n=86)$ & 2.639 & 1.104 & .119 & & & \\
\hline
\end{tabular}

* Significant at $5 \%$ level of significance 
Although results do indicate a significant difference between the first- and fourth-year students in their ability to demonstrate the Composite Skill: Evaluation (with fourth-year students performing slightly better than first-year students on this skill), no systematic difference can be observed between the demonstrated ability of first- and fourth-year students on any other skill. ${ }^{21}$ These results suggest that students in Rwanda may not be improving in their critical thinking ability during university.

However, as discussed in Section 3.2, confounding variables can have a substantial impact on the results of cross-sectional comparisons, so it was necessary to conduct follow-up analysis in order to identify any potentially confounding differences between the first- and fourth-year populations in the sample. Prior research would suggest that the background characteristics of the fourth-year sub-sample should have biased the results in favour of the fourth-year population (in which case the comparative results would reflect an overestimation of the difference in ability between the two populations). However, the lack of systematic correlation between background characteristics and assessment scores within the sample negates the likelihood of such bias. The other potential confounder identified within the sample is the difference between first- and fourthyear participants in the amount of time taken to complete the assessment. Although the overall effect of time taken on the pattern of scores is not significant at the $95 \%$ confidence level, univariate follow-ups do indicate significant results for two of the nine skills: Skill B: Relevance $(F(3)=4.577$, $p=.004$, partial eta squared $=.067)$ and Skill G: Evaluation of Connections $(F(3)=2.863, p=.038$, partial eta squared $=.043$ ). For both of these skills, higher scores appear to be correlated with a longer time taken to complete the assessment. If this effect were to be the result of higher levels of motivation within the first-year population, the lack of observable difference between the first- and fourth-year scores could be interpreted as reflecting a difference in motivation level between the two groups, rather than a bona fide lack of improvement in critical thinking ability. However, the evidence suggests that another explanation is more probable. The systematic relationship identified between language of response and year at university (also discussed in Section 3.2 above) suggests that the fourth-year students within the sample were more comfortable reading English than their first-year counterparts. Given the large amount of written material in the assessment, it seems likely that those first-year students choosing to complete the assessment in English would need more time than the fourth-year students simply to read the content of the assessment. ${ }^{22}$ Limited familiarity

\footnotetext{
${ }^{21}$ Although a significant difference was also detected between first- and fourth-year students in terms of their ability to recognise a lack of information (Skill F), Levene's test was significant for this skill, suggesting that the results of the $t$-test may be unreliable.

22 It does not appear that the difference in language of response between the two groups had a direct confounding effect on the result, as neither multivariate nor univariate analysis indicate any significant relationship between language of response and assessment scores.
} 
with an open-ended test format is also likely to have added to the average time required for firstyear participants to complete the assessment.

This interpretation is further supported by the range of assessment scores obtained by the fourth-year participants in the sample. Although fourth-year students appear to be more adept than first-year students at evaluating connections and using information in decision-making, graduating students are no more proficient than incoming students at demonstrating any of the other individual critical thinking skills assessed in the study. It therefore seems reasonable to conclude that the lack of significant difference between the first- and fourth-year scores in the sample does imply that undergraduates at the participating institutions are not substantially improving in their overall critical thinking ability during their university careers.

\section{Conclusions and Implications}

Although not strictly generalisable to the overall student population in Rwanda, the results outlined in this paper are likely to be indicative of national trends. The three universities included in the study are considered the most prestigious institutions in the country, so one would assume that the study participants would be more proficient at demonstrating critical thinking skills than their counterparts at other institutions. It therefore seems feasible that the overall student population in Rwanda might have even weaker critical thinking skills than the study sample, suggesting that limited critical thinking ability may be a general issue affecting all of Rwanda's tertiary institutions.

These findings carry significant implications for Rwanda's national development strategy. One of the primary assumptions underlying Vision 2020 is that university graduates will be able to fuel the creation of a service-based knowledge economy, thereby attracting foreign investment, increasing domestic capital and allowing the government to reduce its reliance on aid and foreign technical assistance. One crucial component of this vision is the assumption that university graduates will be able to propose new solutions to entrenched problems in Rwandan society. This vision relies fundamentally on the cultivation of critical thinking skills, as graduates need to be able to interpret and use existing evidence in order to make decisions or suggest solutions to problems. The lack of critical thinking ability observed within Rwanda's most prestigious, most resourced public universities therefore presents a serious challenge for the national strategy.

The study results also resonate beyond the Rwandan context. Students appear to be graduating from Rwanda's tertiary institutions with limited critical thinking ability, despite high levels of financial and rhetorical support for public higher education in Rwanda. As most other institutions in the region have not benefited from similar levels of support, it is likely that they are experiencing similar trends in their student populations. The literature linking higher education and development 
largely assumes that university graduates have the ability to think critically about problems. This study raises doubts as to the viability of this assumption in many African contexts.

There are clear implications of such findings for higher education reform efforts across the region. Although problems of academic quality at African universities have been acknowledged for decades, there continues to be very little support for initiatives aimed at improving pedagogy at African institutions. Instead, reforms have focused on improving institutional and system efficiency, despite a growing body of evidence that some efficiency measures may actually be contributing to further declines in academic quality at institutions across the region (Cloete, Bailey, Pillay, Bunting, \& Maassen, 2011; Mamdani, 2007). The results of this study indicate that there is a profound cost to ignoring the importance of student learning outcomes and suggest that concerns around academic quality must move to the centre of the revitalisation debate. Furthermore, the study findings imply that universities in Rwanda may need to alter their teaching practices in order to better support the development of so-called " $21^{\text {st }}$-century skills", including critical thinking, in their student populations (Kivunja, 2014; Trilling \& Fadel, 2009).

Tertiary education has reclaimed a prominent position within development strategies across the region. Although an encouraging trend for the sector, the results of this study suggest that it will be difficult for universities to meet these high expectations unless teaching and learning is prioritised and adequately supported. Investment in the kinds of reforms that directly support student learning within universities is a vital development priority.

\section{Acknowledgements}

I would like to acknowledge the contributions of my doctoral supervisors, Professor Andy Tolmie and Dr Moses Oketch, both of whom provided invaluable assistance throughout the design and implementation of this study; my research assistants, who helped enormously with recruitment, data collection and translation of the assessments; and all the students at NUR, KIST and SFB who volunteered their time to help with this research. 


\section{References}

Africa-UK Engineering for Development Partnership. (2012). Engineers for Africa: Identifying engineering capacity needs in Sub-Saharan Africa. London: Royal Academy of Engineering.

Arum, R., \& Roksa, J. (2011). Academically adrift : limited learning on college campuses. Chicago, IL: University of Chicago Press.

Astin, A. W. (1970). The Methodology of Research on College Impact, Part One. Sociology of Education, 43(3), 223-254.

Astin, A. W. (1991). Assessment for Excellence: The Philosophy and Practice of Assessment and Evaluation in Higher Education. New York, NY: American Council on Education and Macmillan Publishing Company.

Baxter Magolda, M. (1990). Gender Differences in Epistemological Development. Journal of College Student Development, 31(6), 555-561.

Baxter Magolda, M. (1992). Knowing and Reasoning in College Students: gender-related patterns in students' intellectual development. San Francisco, CA: Jossey-Bass.

Benjamin, R., Chun, M., Hardison, C., Hong, E., Jackson, C., Kugelmass, H., ... Shavelson, R. (2009). Returning to Learning in an Age of Assessment: Introducing the Rationale of the Collegiate Learning Assessment. New York, NY: Council for Aid to Education.

Blaich, C., \& Wise, K. (2010). Wabash National Study of Liberal Arts Education 2006-2009: Overview of Findings from the First Year. Retrieved March 6, 2011, from http://www.liberalarts.wabash.edu/study-4th-year-data/

Bradby, H. (2002). Translating Culture and Language: A Research Note on Multilingual Settings. Sociology of Health \& IIIness, 24(6), 842-855.

Brislin, R. W. (1970). Back-translation for cross-cultural research. Journal of Cross-Cultural Psychology, 1(3), 186-216.

Chun, M. (2008). Introduction to Performance Tasks. New York, NY: Council for Aid to Education.

Cloete, N., Bailey, T., Pillay, P., Bunting, I., \& Maassen, P. (2011). Universities and Economic Development in Africa. Wynberg: Centre for Higher Education Transformation.

Cohen, J. (1977). Statistical Power Analysis for the Behavioral Sciences, Revised Edition. London: Academic Press, Inc.

Edwards, R. (1998). A Critical Examination of the Use of Interpreters in the Qualitative Research Process. Journal of Ethnic and Migration Studies, 24, 197-208.

Facione, N. C., \& Facione, P. A. (1997). Critical Thinking Assessment in Nursing Education Programs: An Aggregate Data Analysis. Millbrae, CA: The California Academic Press.

Facione, P. A. (1991). Using the California Critical Thinking Skills Test in Research, Evaluation, and Assessment. Millbrae, CA: California Academic Press.

Filmer, D., \& Pritchett, L. H. (2001). Estimating Wealth Effects without Expenditure Data - or Tears: An Application to Educational Enrollments in States of India. Demography, 38(1), 115-132.

Freedman, S. W., Weinstein, H. M., Murphy, K. L., \& Longman, T. (2011). Teaching History in PostGenocide Rwanda. In S. Straus \& L. Waldorf (Eds.), Remaking Rwanda: State Building and Human Rights after Mass Violence (pp. 297-315). Madison, WI: University of Wisconsin Press.

Giancarlo, C. A., \& Facione, P. A. (2001). A Look Across Four Years at the Disposition Toward Critical Thinking Among Undergraduate Students. The Journal of General Education, 50(1), 29-55.

Gwatkin, D. R., Rutstein, S., Johnson, K., Suliman, E., Wagstaff, A., \& Amouzou, A. (2007). SocioEconomic Differences in Health, Nutrition and Population: Rwanda. Country Reports on HNP and Poverty. Washington, DC: World Bank.

Hagedorn, L. S., Pascarella, E. T., Edison, M., Braxton, J., Nora, A., \& Terenzini, P. T. (1999). Institutional Context and the Development of Critical Thinking: A Research Note. The Review of Higher Education, 22(3), 265-285.

Hambleton, R. K. (1994). Guidelines for Adapting Educational and Psychological Tests: A Progress Report. European Journal of Psychological Assessment, 10(3), 229-244. 
Hatcher, D. L. (2009). The Institutional Assessment of Critical Thinking: A Fifteen-Year Perspective. In J. Sobocan \& L. Groarke (Eds.), Critical Thinking Education and Assessment: Can Higher Order Thinking Be Tested? (pp. 229-246). London, Ont.: Althouse Press.

Hayman, R. (2005). The Contribution of Post-Basic Education and Training (PBET) to Poverty Reduction in Rwanda: balancing short-term goals and long-term visions in the face of capacity constraints. Edinburgh: Centre for African Studies, University of Edinburgh.

Israel, G. D. (1992). Determining Sample Size. Gainesville, FL: University of Florida.

Kember, D., \& Leung, D. Y. P. (2005). The Influence of the Teaching and Learning Environment on the Development of Generic Capabilities Needed for a Knowledge-Based Society. Learning Environments Research, 8, 245-266.

King, P. M., \& Kitchener, K. S. (1994). Developing Reflective Judgment: Understanding and Promoting Intellectual Growth and Critical Thinking in Adolescents and Adults. San Francisco, CA: Jossey-Bass Inc.

KIST Office of Planning \& Development. (2012). KIST Statistics. Kigali: Kigali Institute of Science \& Technology.

Kivunja, C. (2014). Innovative Pedagogies in Higher Education to Become Effective Teachers of 21st Century Skills: Unpacking the Learning and Innovations Skills Domain of the New Learning Paradigm. International Journal of Higher Education, 3(4), 37-48.

Kuh, G. D. and the Documenting Effective Educational Practice Project. (2005). Student success in college: creating conditions that matter. San Francisco, CA: Jossey-Bass.

Kuhn, D. (1995). Microgenetic study of change: What has it told us? Psychological Science, 6, 133139.

Kuhn, D. (1999). A Developmental Model of Critical Thinking. Educational Researcher, 28(2), 16$25+46$.

Kuhn, D. (2005). Education for Thinking. Cambridge, MA: Harvard University Press.

Lehman, D. R., \& Nisbett, R. E. (1990). A Longitudinal Study of the Effects of Undergraduate Training on Reasoning. Developmental Psychology, 26(6), 952-960.

Liamputtong, P. (2010). Performing Qualitative Cross-Cultural Research. Cambridge: Cambridge University Press.

Lonka, K., \& Ahola, K. (1995). Activating instruction: How to foster study and thinking skills in higher education. European Journal of Psychology of Education, 10(4), 351-368.

Mamdani, M. (2007). Scholars in the Marketplace: The Dilemmas of Neo-Liberal Reform at Makerere University, 1989-2005. Dakar: CODESRIA.

McKenzie, D. J. (2003). Measuring Inequality with Asset Indicators. BREAD Working Papers (Vol. 042). Durham, NC: Bureau for Research in Economic Analysis of Development.

McLean Hilker, L. (2011). The role of education in driving conflict and building peace: The case of Rwanda. Prospects, 41, 267-282.

MINEDUC (2007). Rwandan National Qualifications Framework for Higher Education. Kigali: Republic of Rwanda Ministry of Education (MINEDUC).

MINEDUC (2010). Education Sector Strategi Plan 2010-2015. Kigali: Republic of Rwanda Ministry of Education (MINEDUC).

Mines, R. A., King, P. M., Hood, A. B., \& Wood, P. K. (1990). Stages of Intellectual Development and Associated Critical Thinking Skills in College Students. Journal of College Student Development, 31(6), 538-547.

Ministry of Health (MOH) [Rwanda], National Institute of Statistics of Rwanda (NISR), \& ICF Macro. (2009). Rwanda Interim Demographic and Health Survey 2007-08. Calverton, MD: MOH, NISR and ICF Macro.

Moon, J. A. (2008). Critical thinking : an exploration of theory and practice. London: Routledge.

Murenzi, R., \& Hughes, M. (2006). Building a prosperous knowledge economy in Africa: Rwanda as a case study. International Journal of Technology and Globalisation, 2(3/4), 254-269.

NUR Department of Planning \& Development. (2012). NUR Statistics. Kigali, Rwanda. 
Palmer, B., \& Marra, R. M. (2004). College student epistemological perspectives across knowledge domains: a proposed grounded theory. Higher Education, 47, 311-335.

Palmer, R., Wedgwood, R., Hayman, R., with King, K., \& Thin, N. (2007). Educating out of poverty? : a synthesis report on Ghana, India, Kenya, Rwanda, Tanzania and South Africa. Researching the Issues No. 70 (pp. 125). London: Great Britain Department for International Development and Centre of African Studies, University of Edinburgh.

Pascarella, E. T., Seifert, T. A., \& Blaich, C. (2010). How Effective are the NSSE Benchmarks in Predicting Important Educational Outcomes? Change: The Magaizine of Higher Learning, January/February, Accessed online at: http://www.changemag.org/Archives/Back\%20Issues/January-February\%202010/full-howeffective.html.

Pascarella, E. T., \& Terenzini, P. T. (2005). How college affects students (2nd ed.). San Francisco, CA: Jossey-Bass.

Perry, W. G., \& Harvard University Bureau of Study Counsel. (1970). Forms of intellectual and ethical development in the college years : a scheme. New York, NY ; London: Holt Rinehart \& Winston.

Phan, H. P. (2011). Deep Processing Strategies and Critical Thinking: Developmental Trajectories Using Latent Growth Analyses. The Journal of Educational Research, 104(4), 283-294.

Phillips, H. (1960). Problems of Translation and Meaning in Fieldwork. In R. N. Adams \& J. J. Preiss (Eds.), Human Organisation Research: Field Relations and Techniques. Homewood, IL: Dorsey Press Inc.

Piaget, J. (1975). The Development of Thought: Equilibration of Cognitive Structures (A. Rosin, Trans.). Oxford: Basil Blackwell.

Pithers, R. T., \& Soden, R. (1999). Assessing Vocational Tutors' Thinking Skills. Journal of Vocational Education and Training, 51(1), 23-37.

Republic of Rwanda National Council for Higher Education. (2011). National Skills Survey 2010. Kigali: National Council for Higher Education.

Rosenshine, B., \& Meister, C. (1992). The Use of Scaffolds for Teaching Higher-Level Cognitive Strategies. Educational Leadership, 49(7), 26-33.

Rutayisire, J., Kabano, J., \& Rubagiza, J. (2004). Redefining Rwanda's Future: The Role of Curriculum in Social Reconstruction. In S. Tawil \& A. Harley (Eds.), Education, Conflict and Social Cohesion (pp. 315-374). Geneva: UNESCO International Bureau of Education.

Rutstein, S., \& Johnson, K. (2004). The DHS Wealth Index. DHS Comparative Reports. Calverton, MD: ORC Macro.

Saavedra, A. R., \& Saavedra, J. E. (2011). Do colleges cultivate critical thinking, problem solving, writing and interpersonal skills? Economics of Education Review, 30, 1516-1526.

Scheaffer, R. L., Mendenhall, W., \& Ott, L. (2006). Elementary survey sampling (6th ed.). Belmont, CA; London: Duxbury.

Schommer, M., \& Walker, K. (1995). Are Epistemological Beliefs Similar Across Domains? Journal of Educational Psychology, 87(3), 424-432.

SFB Directorate of Academic Services. (2012). Enrolment Report. Kigali, Rwanda: School of Finance and Banking (SFB).

Shavelson, R. (2010). Measuring College Learning Responsibly: Accountability in a New Era. Stanford, CA: Stanford University Press.

Temple, B., \& Young, A. (2004). Qualitative Research and Translation Dilemmas. Qualitative Research, 4(2), 161-178.

Terenzini, P. T., Springer, L., Yaeger, P., Pascarella, E. T., \& Nora, A. (1994). The multiple influences on students' critical thinking skills. Paper presented at the Association for the Study of Higher Education, Orlando, FL.

Terenzini, P. T., Springer, L., Pascarella, E. T., \& Nora, A. (1995). Influences Affecting the Development of Students' Critical Thinking Skills. Research in Higher Education, 36(1), 23-39. 
Tikly, L., \& UK Department for International Development. (2003). Globalisation and skills for development in Rwanda and Tanzania. London: Department for International Development.

Trilling, B., \& Fadel, C. (2009). 21st Century Skills: Learning for Life in Our Times. San Francisco, CA: Jossey-Bass.

Tsui, L. (2001). Faculty Attitudes and the Development of Students' Critical Thinking. The Journal of General Education, 50(1), 1-28.

Tsui, L. (2002). Fostering Critical Thinking through Effective Pedagogy: Evidence from Four Institutional Case Studies. The Journal of Higher Education, 73(6), 740-763.

Vygotsky, L. S., Cole, M., \& Luria, A. R. (1978). Mind in society : the development of higher psychological processes. Cambridge, MA ; London: Harvard University Press.

Walker-Keleher, J. (2006). Reconceptualizing the Relationship between Conflict and Education: The Case of Rwanda. Praxis: The Fletcher Journal of Human Security, 21, 35-53.

Wengraf, T. (2001). Qualitative research interviewing: Biographic narrative and semi-structured methods. London: Sage Publications.

World Bank. (2004). Education in Rwanda : rebalancing resources to accelerate post-conflict development and poverty reduction. A World Bank country study. Washington, DC: World Bank. 